\title{
The Importance of Breastfeeding Based on Islamic Rules and Qur'an
}

\author{
Shahrokh Mehrpisheh ${ }^{1}$, Azadeh Memarian², Maryam Ameri², Mohsen Saberi Isfeedvajani ${ }^{*}$ \\ ${ }^{1}$ Department of Neonatology, Faculty of Medicine, Mazandaran University of Medical Sciences, Sari, Iran \\ ${ }^{2}$ Department of Forensic Medicine, Faculty of Medicine, Iran University of Medical Sciences, Tehran, Iran \\ ${ }^{3}$ Medicine, Quran and Hadith Research Center \& Department of Community Medicine, Faculty of Medicine, \\ Baqiyatallah University of Medical Sciences, Tehran, Iran
}

\begin{abstract}
*Corresponding Author: Mohsen Saberi Isfeedvajani, M.D., Associate Professor, Medicine, Quran and Hadith Research Center \& Department of Community Medicine, Faculty of Medicine, Baqiyatallah University of Medical Sciences, Tehran, Iran. Tel: +98-21-81263617, Email: drsaberihaji@gmail.com
\end{abstract}

Received December 15, 2019; Accepted May 13, 2020; Online Published June 6, 2020

\begin{abstract}
The Qur'an, the word of God, is the best book that has been revealed to guide human beings contains a complete plan of human life. However, in addition to educational, ethical, and religious issues, it also contains valuable scientific information. Several verses in the Holy Qur'an discuss the importance of breast milk and its proper planning. Qur'an also orders up parents, especially mothers, for getting this goddamn blessing to their children. Qur'an verses as well as Islamic hadiths emphasize that breast milk is an unparalleled and comprehensive food that plays a valuable and unique role in the improvement of mental health, physical development, and desirable development of children. Based on Islamic sources, such as the Holy Qur'an and the traditions of the Prophet (PBUH) and Islamic hadith, there are some interesting and important points about breastfeeding, its benefits and its provisions. The Qur'an verses and Islamic hadiths emphasize the importance of breastfeeding and the importance of continuing it until 24 months. The description of these hadiths and verses is presented in the text. Considering the religious and Qur'an educations regarding the importance of breastfeeding infants, it can be concluded that breastfeeding contains the most complete immune and growth factors in the infant. In addition to physical needs, breastfeeding provides emotional and mental development and also gives countless benefits to the mother.

Keywords: Qur'an, Hadith, Breast Milk, Infant, Colostrum
\end{abstract}

\section{Background}

Breastfeeding is one of the most important rights of every child. The importance of the natural nutrition of the baby is so great that the World Health Organization (WHO) and the United Nations International Children's Fund (UNICEF) hold workshops on educating and informing the necessity of breastfeeding and devote one week of the year to the international week of breastfeeding. Today, nutritionists and medical specialists agree on the importance of breastfeeding until two years of age while this issue has been addressed many times in the Qur'an and Islamic narrations on $600 \mathrm{AD}{ }^{1}$

The Qur'an recommends mothers breastfeed their babies for two years. In the Qur'an, God says the father must help the mother breastfeed the baby. Even if the father is dead or does not live in the house, the heir must support the mother and thus force her to breastfeed her babies. ${ }^{2}$ Studies show that the infantile mortality rate (IMR) in lactating infants is four times less than that in artificially-fed infants. Moreover, breastfeeding creates a strong bond between mother and baby that makes the baby happy and secure.
On the other hand, mothers benefit from breastfeeding. For example, breastfeeding women are less likely to have breast cancer than women who have not breastfed their children. $^{2}$ With the increasing progress of science in various fields, new benefits and features of breastfeeding have been recognized. Studying the Qur'an and reviewing the commands of Islam through the narrations and hadiths of the Prophet (PBUH) and the Infallible Imams (AS) and traditional sources, we find that many of these benefits discovered in recent years have already been mentioned. The Holy Qur'an emphasizes breastfeeding until 24 months of age in numerous verses (such as verse 233 of AlBaqarah, verse 15 of Al-Ahqaf, verse 14 of Luqman, verse 23 of Nisa, verse 6 of Talaq, verse 2 of Hajj, verses 12 and 7 of Qasas). In this study, the importance of breastfeeding from the perspective of the Holy Qur'an and Islam has been studied and compared with the obtained scientific findings. This review study was done through collecting data from searching in Google, Scopus, Scholar databases, SID, Magiran, and educational sites using keywords such as breast milk, Islam, Qur'an, and hadiths from 2000 to 2017.

Copyright (C) 2020 The Author(s). This is an open-access article distributed under the terms of the Creative Commons Attribution License (http:// creativecommons.org/licenses/by/4.0), which permits unrestricted use, distribution, and reproduction in any medium, provided the original work is properly cited. 


\section{The Commands of the Qur'an and Islam About Breastfeeding Babies}

The Holy Qur'an pays special attention to breast milk to the extent that the words "Rezae" and "breastfeeding" with their derivatives are mentioned eleven times in the Qur'an: Mothers shall suckle their children for 2 years completely, for whoever desires to fulfill the suckling. It is for the father to provide for them and clothe them with kindness. No soul is charged except to its capacity. A mother shall be harmed for her child, neither a father for his child. And upon the heir is like that. If both desire to wean by mutual consent and consultation, then no guilt shall be on them. And if you desire a wet nurse for your children, then no guilt shall be on you if you hand over what you have given with kindness. And fear Allah, and know that Allah is the Seer of what you do. ${ }^{3}$

In this verse, mothers are advised to breastfeed their children for 2 years. But there are different interpretations of the duration of breastfeeding and its compulsion. As mentioned in Fakhr Razi's great commentary, this noble verse does not accentuate the necessity; because God says, "Those mothers who want to finish breastfeeding." That is, it suspends the end of breastfeeding upon the mother's willing, thus it is crystal clear that keeping breastfeeding for two years is not necessary. Furthermore, God says, "Parents can wean their baby in case of mutual consent and consultation". Hence, this expression clearly states that the extent is not obligatory and mothers have the right to breastfeed their children for two whole years if they want to fully breastfeed, but it is also permissible to wean their baby by the end of two years. ${ }^{4}$

However, the Prophet $(\mathrm{PBUH})$ did not consider the cessation of breastfeeding before this period as "Rezae" and said: "The duration of breastfeeding is 21 months and whatever is less than this period, then there is oppression and loss on the infant's right and if you want to end breastfeeding It must be completed for two years". 9 Inspired by Islamic narrations, jurists and commentators, according to various interpretations of the verses of the Holy Qur'an and Islamic narrations, have concluded that the minimum period of pregnancy is 6 months and the maximum useful period of breastfeeding is twenty-four months.

Some of our interpreters, including Ibn Abbas believe that this duration (2 years) is not the same for infants and only involves those who are born 6 months earlier. ${ }^{5,6}$ Ibn Abbas used verse 15 of Al-Ahqaf as a reason indicating that the duration of pregnancy and weaning is 30 months, thus the shorter the time of delivery is, the longer will be the weaning period and vice versa. ${ }^{4,7}$ From the content of this verse, we can find the consistency of feeding premature infants with breastfeeding duration, because mothers who give birth to premature infants secrete colostrum from 2 weeks to 21 days, while the duration of colostrum secretion in premature infants is $4-5$ days. This is interesting due to the lack of development of the premature baby's immune system. ${ }^{8}$
In verse 233 of Al-Baqarah, God says: It is obligatory for whom the child was born [father], to provide the mother with healthy nutrition and proper cloth (during the breastfeeding period; even if she is divorced). No one is obliged to overdo something beyond their capability! Neither the mother nor the father (because of the dispute with the father) has the right to harm the child. It is also necessary for the heir to do so [to afford mother during breastfeeding]. And if both of them want to wean the baby earlier by mutual consent (sooner), there is no sin on them. And if you want to take a midwife for your children (with the inability or disagreement of the mother), you won't be blamed; provided that you pay for the mother's past rights properly. And avoid disobeying God's command, and know that God is sighted to what you do. ${ }^{3}$

Apart from 322 of Al-Baqarah and verse 15 of Surah AlAhqaf, God, in verse 14 of Surah Al-Luqman, emphasizes again the importance of breastfeeding: "And we charged the human concerning his parents, for his mother bore him in weakness upon weakness, and his weaning was in two years. Be thankful to Me and your parents, you will return to me."10

Because of the great importance of breastfeeding, verse 6 of Surah Talaq discusses the need to respect infant rights over how to wean a child: Do not change mother's accommodation until the end of breastfeeding and agree with the widowee as much as possible on this issue, and even if they do not agree on this, continue to breastfeed the baby. ${ }^{11}$

In addition to the recommendations and emphases of the Holy Qur'an on breastfeeding, this issue has been considered and emphasized in Islamic traditions and hadiths. Amir Al-mu'minin (AS) says: No milk is healthier than breast milk for the baby to consume. ${ }^{12}$

In another Hadith from the Holy Prophet (PBUH), we hear that: God Almighty provides babies with fine provisions in the mother's breasts; In one part water and in the other part, his food. Since the birth of the child, he has provided them with provisions proportionate to his needs. ${ }^{13,14}$

Even today, mothers are recommended to breastfeed babies from both breasts in the first weeks to stimulate milk production. In the following weeks, one or both breasts can be used based on the baby's needs. In this case, breastfeeding should be used periodically. For example, if an infant begins with the left breast in one meal, he should begin with the right breast in the next meal. ${ }^{15,16}$ Therefore, these precise and calculated rules and the warnings mixed with them clearly show that breastfeeding and rights of infants and mothers are greatly significant in Islam. Breastfeeding is so important that the Holy Prophet (PBUH) said to Hoola Attar: "So when the mother gives birth and begins breastfeeding the baby, a glowing light will glitter for mother in Day of Judgment for each time of sucking mother's breast, and everyone from the past and the future will see it and get surprised. And this will be 
recorded in the Action letter...So if she weans his baby, may God Almighty say to him, O woman! Know that I have forgiven all your sins, so resume your action. ${ }^{16}$

\section{The Effect of Breastfeeding on the Emotional Development and Mental Health of the Baby From the Perspective of Islam and the Qur'an}

One of the things that can help your baby relax is hugging the baby while breastfeeding. Although both mother's arms are soothing to the baby; studies show that the left arm is a better place to breastfeed. ${ }^{17}$ Imam Jafar Sadegh (AS) advises mothers to put their infants to sleep on the left side of their chests. ${ }^{9}$ It seems that since the music of the mother's heartbeat is soothing for the child, putting him to sleep on the left side makes the baby hear his heartbeat and find the mother's love.

Islamic hadiths even point out that the beliefs, spiritual and intellectual characteristics of the mother or midwife affect the infant and lead him to the good or bad. Regarding the positive effect of breast milk on the child, they said, "They Congratulated Sheikh Ansari's mother for having such a child". The Sheik's mother replied: "Such a position is normal in the face of troubles and difficulties I have stood in training him." For example, "I never breastfed her without ablution throughout her infancy". ${ }^{18}$ In this regard, Islam is very sensitive in choosing a midwife to breastfeed the baby and advises Muslims to leave their baby to a midwife who is wise, beautiful, good-natured, healthy, and religious. Because milk affects how a child is raised. Therefore, the Holy Prophet of Islam says:

"Be careful not to hire a stupid woman to breastfeed your children; because the milk nurtures the child in the same state as the midwife". ${ }^{16}$ Further, Islam commands Muslims to earn Halal living by working hard. If the mother's nutrition is Haram or suspicious, the child's mental health is at risk, thus mothers should be careful about their nutrition. Since rotten and contaminated food makes a person sick, the milk produced by eating Haram food affects the human's heart and soul. ${ }^{19}$

Islam recommends mothers increase breast milk. According to a hadith from the Holy Prophet (PBUH): "Sucking the breast by a child increases milk and the reward of nocturnal breastfeeding equals making seventy servants free in favor of God." Nowadays, breastfeeding experts say that the most important factor in increasing breast milk is the proper sucking of milk from the breast and emptying the breast by the baby. If the secreted milk is not emptied successively, its production and secretion will gradually decrease. When a baby sucks, neurotransmitters are transmitted from the nipple to the hypothalamus in the brain and increase the prolactin secretion (milkstimulating hormone) by tenfold. ${ }^{20}$

\section{The Effect of Breast Milk on the Physical Development of the Child From the Perspective of Islam and the Qur'an}

Breast milk suffices for the growth of the baby by the end of six months, and the baby does not need any food or drink. Hazrat Amir al-Mu'minin (AS) says: Not any milk is healthier than mother's milk. The teeth of babies breastfed with mother's milk are much stronger than those of babies fed with artificial milk and are more resistant to diseases. ${ }^{12}$ Colostrum, which is the yellow milk that flows into the mother's breasts since giving birth, contains nutritional substances that are the first and best vaccine to protect the baby and fight infectious diseases. The importance of colostrum is so great that some Muslim Faghihs have considered it necessary to feed their children with it, including Allama Majlisi in Haliyah Al-Muttaqeen, who writes: "A group of religious experts (Olama) consider it Wajib (obligatory) to feed their children with colostrum. If she does not do so, the baby will not be alive or survived, or strengthened". ${ }^{21}$ In juridical books and Islamic customs, such as "Jawahar al-Kalam" and "Haliyeh al-Muttaqin", nutrition with colostrum is emphasized., 1,22,23 God says: Indeed, in the cattle, there is a lesson for you. We provide fresh and pure milk for you to drink which is in their bellies, between the filth (bowels) and blood, pure milk, which is sweet to those who drink (Surah Nahl, verse 66). ${ }^{24,25}$

In this verse, the Qur'an explicitly states that an object is produced from food digested in the stomach. Digested food turns into blood and milk is formed from the blood. The formed milk has neither the color of blood nor its taste and smell. This action (conversion of blood into milk) has not been denied by any of the scholars and confirms the words of the Qur'an. In addition, breast milk increases the baby's immunity against many parasitic, fungal, bacterial, and viral diseases, and even protects against cardiovascular disease, which is common among the elderly. ${ }^{26}$ Hitherto, no drugs or medications have been developed to increase children's IQ, but breast milk can increase a baby's IQ by up to eight-unit. It is worth noting that breast milk is constantly changing in proportion to the growth of the baby and the evolution of his physical condition and needs. ${ }^{26}$ Moreover, breast milk fat decreases with each time of breastfeeding and then gradually increases.

For this reason, experts believe that in each time of breastfeeding, one breast must be completely emptied and the next time, the other one. Due to the fattiness of milk, the baby gets full and does not overeat, thus, she/ he becomes less obese. Obesity of babies fed with artificial milk during this period causes cardiovascular diseases and diabetes in adulthood.

This view of nutritionists is consistent with the words of Imam Sadiq (AS). He (AS) also considers breastfeeding a baby from both breasts is the best way. In a narration, the Imam said: "Oh mother of Isaac, Do not breastfeed from one breast but from both breasts, one for food and the other instead of water". ${ }^{27}$

Breast milk contains rich vitamins and minerals as well as sugar. This substance is so complete and unique that the Holy Prophet (PBUH) said: "Milk is the king of beverages." In another narration, He said, "nothing can replace food and drink but milk". ${ }^{15}$ 


\section{Benefits of Breastfeeding for Mother}

Breastfeeding by the mother is beneficial for the baby and the mother. Breastfeeding causes nervous reactions and the womb will be contracted in this period. These muscular contractions cause adherence to blood vessels and eventually prevent bleeding. Breastfeeding early eliminates excessive fat stored in the body during pregnancy and reshapes the body as before the pregnancy. Therefore, it seems that part of the Holy Quran's emphasis on breastfeeding and extending its time to 24 months indirectly reflects the mother's health.

Moreover, breastfeeders are at lower risk of breast cancer than women who have never breastfed. Breastfeeding mothers are immune to diseases such as osteoporosis, breast cancer, uterine cancer, ovarian cancer, and type 2 diabetes. Although the benefits of breastfeeding for the mother are not directly stated in Islamic verses and hadiths (due to the illiteracy of Suadi Arabian Society), Islam has comprehensively recommended breastfeeding through hadiths and encouraging messages. Umm Salma, the wife of the Prophet, says: I asked the Holy Prophet (PBUH) that men are mostly rewarded. Do women also receive these rewards? He said: "Yes, when a woman becomes pregnant, she is like a fasting person who stays up the whole night and has Jihad with her life and property, and whenever she gives birth, she will get a reward that no one is aware of its greatness. Whenever she breastfeeds his baby, she will be rewarded for each time of sucking which equals to the release of a slave from the children of Ishmael, and when she weans her baby, a sublime angel tells her: Resume your actions, since God has forgiven you". ${ }^{27,28}$

\section{Discussion and Conclusion}

Islam emphasized the need for breastfeeding 1400 years ago, long before modern studies. The Holy Qur'an and hadiths explain the details of the importance of drinking colostrum at the first hours of birth. Studies have also shown that breastfeeding in the first 60 minutes is effective in keeping exclusive breastfeeding. ${ }^{29}$

According to the perspective of the Holy Qur'an and the hadiths, the optimal time for breastfeeding is 24 months. The scientific findings conclude that this period fulfills the mental and physical health of the baby. Studies show that proper breastfeeding prevents cardiovascular diseases and diabetes in adulthood. Therefore, the emphasis of the Qur'an and hadiths on breastfeeding and its duration is a comprehensive recommendation to preserve mother and baby's health. Breastfeeding, from God Almighty, is so important that he commands men to provide all the expenses of food and clothing during breastfeeding so that the mother can breastfeed the baby with peace of mind. God Almighty emphasizes that parents do not have the right to consider the child's destiny as a means of settling their differences, and men must not violate the right for custody and mother's caring by taking infants from mothers during the breastfeeding period.

Following all these orders, Islam recommends taking

\section{Review Highlights}

\section{What Is Already Known?}

One of the main and most important rights of every child is breastfeeding. The importance of natural infant nutrition has led the World Health Organization and UNICEF to hold training courses every year and raise awareness of the need for breastfeeding, and one week a year is designated as World Breastfeeding Week. Today, nutritionists and medical scientists all agree on the importance of breastfeeding until the age of two.

\section{What This Study Adds?}

The religion of Islam about 1400 years ago, much earlier than today, has emphasized the need for breastfeeding. According to religious and Quranic teachings on the importance of breastfeeding, which contains the most complete factors of safety and growth of the baby, breast milk is a unique and comprehensive food that in addition to meeting the physical needs and optimal development of children, has a valuable and unique role in promoting mental and spiritual health. Also, breastfeeding brings countless benefits to the mother.

midwives for babies who cannot consume breast milk. But Islam is very fussy in choosing a midwife to breastfeed the baby. God advises men to choose a good midwife for their baby if they do not agree with their spouse. Because the beliefs and intellectual characteristics of the midwife affect the infant and lead him toward the good or bad.

It seems that such perfect advice and instructions come only from the word of revelation and nowhere. Finally, we find the necessity of breastfeeding and following religious instructions by examining the miracle of revelation verses and precious hadiths concerning the importance of breastfeeding and the uniqueness of its compounds.

\section{Authors' Contributions}

All authors contributed equally to this study.

\section{Conflict of Interest Disclosures}

The authors declare that they have no conflicts of interest.

\section{Ethical Approval}

Not applicable.

\section{References}

1. Aqamiri SP. Rezae in the Quran and modern science. Besharat Journal. 2008;12(68):52-56.

2. Hawwas AW. Breast feeding as seen by Islam. Popul Sci. 1988;8:55-58.

3. The Holy Quran. Surah Al-Baqarah, Verses 233. Tehran: Office of Historical and Islamic Studies; 2011.

4. Fakhre Razi M. Tafsir Al-Kabir. Beirut: Dar Al-Kotob Al-Ilmiyah Publications; 1999.

5. Al-Tabrisi A. Majma Al-Bayan Fi Tafsir Al-Quran. 1st ed. Tehran: Osveh Publications; 1999.

6. Tusi A. Al-Tibbyan Fi Tafsir Al-Quran. 1st ed. Islamic Publishing 
Institute (Teacher's Society); 1992.

7. The Holy Quran. Surah Al-Ahqaf, Verses 15. Tehran: Office of Historical and Islamic Studies; 2011.

8. Zahed Pasha Y, Zahed Pasha E, Baleghi M. Islam and breastfeeding. Journal of Babol University of Medical Sciences. 2013;15(Suppl 1):15-20. doi:10.18869/acadpub. jbums.15.1.15.

9. Ameli SH. Wasail Al-Shia. 1st ed. Beirut: Dar Al-Ehya Al-Torath Al-Arabi; 1992.

10. The Holy Quran. Surah Al-Logman, Versus 14. Tehran: Office of Historical and Islamic Studies; 2011.

11. The Holy Quran. Surah Al-Talaq, Versus 6. Tehran: Office of Historical and Islamic Studies; 2011.

12. Al-Kulayni M. Al-Kafi, Vol 4. Tehran: Dar Al-Kotob Al-Islamiyah Publications; 1984.

13. Sheikh Sadoq A. Al-Mavaez. Tranzlated by Atarodi Qochani A. Qom: Hazrat-e-Abbas Publications; 2015.

14. Mohaddes Noori MH. Mustadrak AI-Wasail. Qom: Ahl Al-Byte Institute; 1987.

15. Mohtasham Amiri Z, Jafari Shakib A. An example of preventative medicine in the teachings of the Quran. Journal of Medical Ethics. 2010;3(9):93-110.

16. Zarneshan S, Rezvani Mofrad A. Protection of "the right to breastfeed" in Islam and international human rights system. Comp Law Rev. 2017;8(2):583-606. doi:10.22059/ jcl.2017.236561.633517.

17. Center for Islamic Studies of Strasbourg. Thoughtful Brain of the Shia World; Imam Jafar Sadiq. Translated by Mansouri Z. Tehran: Badraqe Javidan Publications; 2015.

18. Ansari M. Life and Personality of Sheikh Ansari. Qom: Fares Al-Hijaz Publications; 2005.

19. Mazaheri H. Child Upbringing from the Perspective of
Islam. Tehran: International Publications (affiliated to Islamic Propaganda Organization); 2016.

20. Bayyenat S, Ghazizade Hashemi SA, Purbaferani A, Saeid $\mathrm{M}$, Khodaee $\mathrm{GH}$. The importance of breastfeeding in Holy Quran. Int J Pediatr. 2014;2(4.1):339-347. doi:10.22038/ ijp.2014.3396.

21. Mohammadian B. Another Look at the Rights of Children from the Point of Islam View. Edited by Rahimi A. Tehran: Parents \& Coaches Association Publication; 2011.

22. Najafi MH. Javaher Al-Kalam. Qom: Islamic Publications Office (affiliated to Jama'a al-Modarsin); 2015.

23. Majlesi MB. Heliyat Al-Mottaqin. Qom: Holy Mosque of Jamkaran; 2009

24. The Holy Quran. Surah AI-Nahl, Versus 66. Tehran: Office of Historical and Islamic Studies; 2011.

25. Makarem Shirazi N. Tafsir Nemooneh. Tehran: Dar Al-Kotob Al-Islamiyah Publications; 2001.

26. Velayati M. Jurisprudential study of milk bank based on nutritional parameters, formula of breast milk and medical immunological and physiological mechanisms. Innovation in Food Science and Technology. 2016;8(2):123-133.

27. Heidari MS, Yadollahpour MH, Hoseiny Z, Basirat Z. Comparative study of the importance of breast milk from Quran and medical science approach. Islam and Health Journal. 2014;1(3):69-77.

28. Sattari M, Serwint JR, Levine DM. Maternal implications of breastfeeding: a review for the internist. Am J Med. 2019;132(8):912-920. doi:10.1016/j.amjmed.2019.02.021.

29. ZahedPasha E, Zenoozi F, Baleghi, M, Bijani A, Zahed Pasha Y. Association of breastfeeding in the first hours of life with duration of lactation. Journal of Babol University of Medical Sciences. 2012;14(6):17-24 